\title{
PENGGUNAAN BAHASA INDONESIA DI KALANGAN GENERASI MILENIAL
}

\author{
Nofitasari $^{1)}$, Sri Wahyuni ${ }^{2)}$, Saleha Astri Rahaningmas ${ }^{3)}$, M. Izhar Mahendra ${ }^{4}$ \\ ${ }_{1,2,3,4)}$ Program Studi Pendidikan Bahasa dan Sastra Indonesia \\ Fakultas Sastra, Universitas Muslim Indonesia \\ Email: Nofitasari1120@gmail.com
}

\begin{abstract}
Abstrak
Bahasa Indonesia adalah jati diri sekaligus identitas bangsa Indonesia. Bahasa Indonesia memegang peranan penting pada semua aspek kehidupan. Saat ini adalah generasi milenial, masa adanya peningkatan penggunaan dan keakraban dengan komunikasi, media dan teknologi digital. Hal tersebut berdampak pada perkembangan bahasa Indonesia, keadaan yang ada sekarang adalah fungsi bahasa Indonesia mulai digantikan atau tergeser oleh bahasa asing dan adanya perilaku yang cenderung menyelipkan istilah bahasa asing. Padahal padanan dalam bahasa Indonesianya ada, dikarenakan sikap yang menyakini bahwa akan terlihat modern, dan terpelajar dan dengan alasan mempermudah komunikasi di era milenial. Istilah generasi Milenial dewasa ini sedang viral, khususnya di media sosial. Netizen (warganet) sering menyebutnya dengan kids jaman now. Generasi ini hadir sebagai bentuk diferensiasi antara generasi zaman dulu yang eksis di tahun 90-an dengan generasi yang sedang eksis di zaman sekarang. Dari segia usia, bisa dikatakan generasi milenial adalah mereka yang saat ini berada pada rentang umur 15-30 tahun. Bahasa meliputi ungkapan, pengucapan kata, dan kontruksi yang telah dipakai dalam jangka waktu yang lama. Ungkapan, pilihan kata, dan konstruksi itu dipilih oleh penutur dari generasi yang berbeda dengan frekuensi yang berbeda pula. Bahkan, ada ada bagian bahasa lebih-lebih pada tataran leksikal dan sintaksis, yang dirasakan berbeda oleh para penutur yang "modern" dengan yang "kuno".
\end{abstract}

Kata Kunci: bahasa Indonesia, generasi milenial

\section{PENDAHULUAN}

Jati diri sebuah bangsa salah satunya dapat dilihat dari bahasa, tak terkecuali bahasa Indonesia sebagai bahasa nasional bangsa Indonesia. Bahasa Indonesia memegang peranan penting pada semua aspek kehidupan sehari-hari warga negara Indonesia dalam hal berkomunikasi. Sering kali dengan alasan mempermudah komunikasi, tidak sedikit orang menggunakan bahasa Indonesia dengan tidak baik dan benar. Karena itu, perlu adanya kepatuhan dalam penggunaan bahasa Indonesia, agar pertahanan bahasa Indonesia tetap terjaga, mengingat banyak pengaruh dikarenakan globalisasi, salah satunya pada sektor pendidikan. Penting untuk dilakukan peningkatan pendidikan bahasa Indonesia, baik di SD, SMP, SMA, atau sederajat hingga perguruan tinggi. Dimulai dari peningkatan kemampuan berbahasa para pengajar, yang kemudian diharapkan dapat menjadi contoh untuk peserta ajarnya. Jika kita melihat di lapangan, para pengajar maupun peserta ajar belum sepenuhnya menggunakan bahasa Indonesia secara baik dan benar.

Selain sebagai jati diri atau identitas bangsa, fungsi bahasa Indonesia yaitu merupakan lambang kebangsaan nasional dan pemersatu berbagai lapisan masyarakat yang berbeda latar belakang 
sosial budaya. Seiring dengan perkembangan zaman bahasa Indonesia mengalami perkembangan, baik ke arah positif maupun negarif. Keadaan yang ada sekarang adalah fungsi bahasa Indonesia mulai digantikan atau tergeser oleh bahasa asing dan adanya perilaku yang cenderung menyelipkan istilah asing, padahal padanan dalam bahasa Indonesianya ada, dikarenakan sikap yang menyakini bahwa akan terlihat modern, dan terpelajar jika menggunakan istilah atau bahasa dalam berkomunikasi pada pergaulan sehari-hari. Hal tersebut berdampak pada eksistensi bahasa Indonesia.

Generasi milenial ialah masa adanya peningkatan penggunaan dan keakraban dengan komunikasi, media dan teknologi digital seperti sekarang ini. Generasi yang hidup di era milenial ini memiliki karakter yang khas. Sejak di bangku sekolah sudah menggunakan gawai dan menjadikan internet sebagai kebutuhan pokok, selalu terhubung dengan internet, supaya dapat mengakses hal-hal baru atau sekedar bersosialisasi dalam media sosial. Generasi saat ini disebut dengan generasi milenial, yaitu generasi yang lahir antara tahun 1980 sampai 2000-an.

\section{PEMBAHASAN}

\section{Bahasa Indonesia dan Generasi Milenial}

Bahasa adalah suatu media yang digunakan untuk menyampaikan dan memahami gagasan, pikiran, dan pendapat. Bahasa juga media komunikasi utama di dalam kehidupan manusia untuk berinteraksi (Surahman, 1994:11).

Secara garis besar, bahasa dapat dilihat dari tiga sudut pandang, antara lain: sudut pandang bentuk dan sudut pandang makna (Martinet, 1987). Bentuk bahasa berhubungan dengan keadaannya dalam mendukung perannya sebagai sarana komunikasi untuk berbagai kepentingan komunikasi pemakai bahasa, dan hubungannya dengan aspek nilai dan aspek makna adalah perannya yang terkandung dalam bentuk bahasa yang fungsinya sebagai alat komunikasi ketiga unsur tersebut secara keseluruhan dimiliki oleh semua bahasa di dunia.

Bahasa menunjukkan bangsa. Itulah kata bijak yang sejak lama tertanam dalam benak kita. Bahasa kita adalah bahasa Indonesia, bahasa yang bukan hanya menjadi kebanggaan dan identitas, tapi juga alat persatuan yang berjasa dalam sejarah Indonesia. Namun bagaimana sekarang? Di era milenial seperti saat ini masihkah ada kebanggaan menggunakan bahasa Indonesia? Salah satu kelemahan orang Indonesia untuk bersaing dengan orang luar negeri adalah bahasa. Kultur bahasa Indonesia yang tidak menggunakan bahasa asing sebagai bahasa pengantar membuat sebagian besar rakyat Indonesia hanya bisa berbahasa Indonesia. Kesadaran itulah yang kini mulai disadari keinginan belajar dan menggunakan bahasa asing mulai tumbuh.

Namun seiring waktu keinginan belajar bahasa asing justru membuat bahasa Indonesia terpinggirkan. Banyak anak usia sekolah, terutama kaum milenial yang tinggal di kota besar, yang terlihat gagap berbahasa Indonesia. Banyak diantara mereka yang bahkan lebih fasih berbahasa asing daripada berbahasa Indonesia. Mengapa itu bisa terjadi? Keinginan mempersiapkan anak memasuki era globalisasi tentu boleh-boleh saja. Namun jika itu mengorbankan jati diri bangsa apalah gunanya. Namun yang terjadi tidak seperti yang diperkirakan, 
anak-anak justru semakin asing dengan bahasa lokal. Menjamurnya bahasa bilingual memperparah kondisi ini, beberapa sekolah yang berlabel "sekolah Internasional" bahkan menggunakan bahasa asing sebagai bahasa pengantar kegiatan belajar satu mata pelajaran yang diajarkan hanya beberapa jam dalam seminggu.

Kehidupan dan interaksi anak muda milenial pun terlepas dari "kontaminasi bahasa". Penggunaan istilah-istilah yang entah dari mana asalnya semakin menghilangkan wujud asli bahasa Indonesia. Di era milenial saat ini, bahasa Indonesia banyak tercampur dengan bahasa asing. ‘kids jaman now' menggantikan istilah remaja masa kini 'woles' yang menggantikan santai, konon diambil dari kata slow yang diucapkan terbalik. Serta masih banyak istilah-istilah yang sebelumnya tidak terkenal.

Secara umum, remaja adalah waktu manusia berumur belasan tahun. Pada masa remaja manusia tidak dapat disebut sudah dewasa tetapi tidak dapat pula disebut anak-anak. Masa remaja adalah masa peralihan manusia dari anak-anak menuju dewasa, remaja merupakan peralihan antara masa anak dan masa dewasa yang berjalan antara umur 12 tahun sampai 21 tahun. Remaja memiliki tempat di antara anak-anak dan orang tua karena sudah tidak termasuk golongan anak tetapi belum juga berada dalam golongan dewasa atau tua. Masa remja menunjukkan dengan jelas sifat transisi atau peralihan karena remaja belum memperoleh status dewasa dan tidak memiliki status anak.

\section{Bahasa Indonesia Yang Baik dan Benar}

Sering kita dengar ungkapan "gunakanlah bahasa Indonesia yang baik dan benar". Terhadap ungkapan itu timbul banyak reaksi. Pertama, orang mengira bahwa kata baik dan benar dalam ungkapan itu mengandung arti atau makna yang sama atau identik. Sebenarnya tidak, justru ungkapan itu memberikan kesempatan dan hak kepada pemakai bahasa untuk menggunakan bahasa secara bebas dengan keinginannya dan kemampuannya dalam berbahasa.

Berbahasa yang baik ialah berbahasa sesuai dengan "lingkungan" bahasa itu digunakan. Dalam hal ini beberapa faktor menjadi penentu. Pertama, orang yang berbicara; kedua, orang yang diajak berbicara; ketiga, situasi itu formal atau nonformal; keempat, masalah atau topik pembicaraan. Sedangkan bahasa yang benar adalah bahasa yang sesuai dengan kaidahnya, aturannya, bentuk strukturnya. Kalau berbahasa Indonesia baku harus seperti bahasa yang kaidahnya tertulis dalam buku-buku tata bahasa. Sebaliknya, jika menggunakan salah satu dialek, dialek Jakarta misalnya harus betulbetul bahasa Jakarta seperti yang digunakan oleh penduduk asli Jakarta itulah dimaksud dengan kata benar.

Meninggalkan suatu kebiasaan yang telah menjadi tradisi akan berakibat besar dalam kelangsungan hidup masyarakat tersebut. Begitu juga yang akan terjadi pada bahasa Indonesia yang disempurnakan jika semakin ditinggalkan oleh masyarakatnya. Dampak buruk yang dapat dirasakan langsung adalah menurunnya nilai kesopanan remaja ketika berbicara dengan orang yang lebih tua. Sedangkan dampak tidak langsungnya adalah merusak bahasa nasional itu sendiri. Mungkin, beberapa tahun kedepan masih bisa menggunakan bahasa Indonesia yang baik dan benar, namun bagaimana dengan 
lima puluh tahun yang akan datang? Apakah bahasa Indonesia masih bisa bertahan? Atau hilang ditelan "bahasa gaul'?

Hal ini menjadi tugas kita sebagai remaja sekaligus pelajar yang masih peduli dengan Bahasa Indonesia. Kita tidak dapat memungkiri bahwa "bahasa gaul" telah mengikis dan merusak bahasa Indonesia. Oleh karena itu, sebagai generasi muda marilah kita menjaga dan melestarikan Bahasa Indonesia.

\section{Penggunaan Bahasa Indonesia di Kalangan Remaja}

Dahulu bahasa Indonesia digunakan dengan baik dan benar sesuai kaidah berbahasa yang tepat. Namun kini, seiring dengan perkembangan teknologi dan pengaruh budaya luar, bahasa Indonesia rusak justru di tangan para pemudanya sendiri. Penggunaan bahasa Indonesia oleh remaja masa kini, terutama di kota-kota besar, sangat tidak sesuai dengan kaidah berbahasa yang baik dan benar. Remaja mencampur adukkan Bahasa Indonesia dengan bahasa-bahasa daerah dan bahasa asing kemudian menyebutnya sebagai "bahasa gaul" kosakata baru banyak muncul untuk mengganti kata-kata dalam bahasa Indonesia. Misalnya "gue" yang berarti bahasa Betawi, digunakan untuk mengganti "saya"; "loe" untuk mengganti kata "kamu"; "nyokap-bokap" untuk mengganti kata "ayah-ibu" dan muncul kosa kata yang tidak jelas artinya seperti "lebay", "kamseupay" dan muncul partikel-partikel seperti `sih`dan `dong`.

Tronisnya, penggunaan bahasa gaul ini tidak hanya di lingkungan pergaulan, namun telah mendarah daging dan tak jarang digunakan remaja di sekolah, bahkan ketika tes atau pelajaran bahasa Indonesia sekalipun. Di sekolah, remaja spontan berbicara dengan bahasa gaul dengan teman dan guru karena telah terbiasa menggunakannya dalam percakapan sehari-hari dan menulis pesan singkat. Mulai dari remaja di tingkat sekolah menengah pertama, sekolah menengah atas, sampai para mahasiswa. Sebagian besar dari mereka saat berkomunikasi telah jauh dari susunan keIndonesiaan yang baik dan benar, walaupun seperti yang kita ketahui mereka semua berada dalam kalangan akademik yang masih mendapatkan pendidikan. Tetapi pada kenyataannya bahasa Indonesia yang telah disusun rapi dengan EYD telah jauh dilupakan.

Dari pengaruh tersebut didapatkan tiga bahasa yang digunakan remaja saat ini, yaitu yang pertama bahasa prokem atau bahasa gaul merupakan bahasa yang digunakan dikalangan pemuda ataupun remaja yang dalam penggunaan bahasa seenaknya sendiri sehingga masyarakat tidak dapat memahaminya dalam proses komunikasi. Bahasa gaul merupakan bahasa yang digunakan dikalangan remaja karena pengaruh arus globalisasi. Bahasa gaul juga merupakan ragam bahasa Indonesia nonstandar yang lazim digunakan di Jakarta pada tahun 1970-an yang kemudian digantikan oleh ragam yang disebut sebagai bahasa gaul, bahasa karena pengaruh waktu. Kedua yaitu bahasa asing, bahasa asing merupakan bahasa yang tidak digunakan oleh orang yang tinggal sebuah tempat tertentu misalnya, bahasa Indonesia yang dianggap sebagai sebuah bahasa yang asing di Australia. Bahasa asing juga merupakan sebuah bahasa yang tidak digunakan di tanah air atau negara asal seseorang. 
Sangat disayangkan bahwa bahasa asing terutama bahasa Inggris telah memperkaya kosa kata bahasa Indonesia dan yang tidak dipungkiri lagi banyak diantara mereka yang menuliskan kosa kata asing padahal kosakata itu telah di Indonesiakan. Dan yang ketiga adalah bahasa daerah yang merupakan warisan budaya dari daerahnya masing-masing di wilayah Indonesia. Bahasa daerah merupakan identitas dari daerahnya masing-masing. Indonesia kaya akan bahasa daerah, tetapi seperti yang kita ketahui penggunaannya kadang tidak sesuai pada waktunya. Remaja yang berada dalam suasana formal dan lingkungan akademik seharusnya menggunakan bahasa Indonesia dengan baik dan benar tetapi kenyataannya mereka masih membawa bahasa asalnya atau bahasa daerah.

\section{Bahasa Indonesia dan Media Sosial}

Tidak dapat dimungkiri, perkembangan media sosial dewasa ini turut berpengaruh terhadap perkembangan bahasa Indonesia. Bahasa Indonesia yang berkedudukan sebagai bahasa nasional digunakan sebagai alat pengembangan kebudayaan nasional, ilmu pengetahuan dan teknologi. Kebudayaan nasional yang beragam, rasanya sulit disebarluaskan kepada seluruh masyarakat yang juga beragam bahasa daerah dengan menggunakan bahasa selain bahasa Indonesia. Hal ini juga berlaku dalam penyebarluasan ilmu pengetahuan dan teknologi modern, termasuk dalam penggunaan media sosial.

Media sosial dalam praktiknya menggunakan bahasa sebagai medium utama untuk saling berinteraksi. Bahasa menjadi prasyarat mutlak agar komunikasi para penggunanya dapat berjalan lancar. Di Indonesia, media sosial seperti facebook, instagram, dan twitter, menjadi media yang paling populer digunakan semua lapisan masyarakat untuk berkomunikasi atau sekedar unjuk diri.

Setiap generasi tumbuh dengan cirinya masing-masing. Kehidupan manusia yang sekarang ini terjadi dan kita saksikan bersama, adalah kehidupan yang serba misterius dan makin sulit ditebak arahnya. Perubahan yang terjadi dalam skala luas makin ditentukan oleh kebijakan individu (people to people), bukan hanya ditentukan negara atau organisasiorganisasi. Contoh yang sangat jelas misalnya, kita bisa menciptakan popularitas individu melalui instagram, facebook, atau situs media sosial lainnya dengan cepat dan praktis. Kita bisa belajar banyak hal melalui youtube, membaca informasi di internet, berinteraksi dengan milyaran orang di seluruh dunia dengan sekali klik. Itulah umumnya generasi milenial, generasi teknologi informasi, yang berbeda dengan generasi sebelumnya, yaitu generasi $\mathrm{x}$, baby boomers, hingga generasi tradisional.

\section{Peran Generasi Milenial dalam Upaya Internasionalisasi Bahasa Indonesia}

Bahasa Indonesia sebagai bahasa resmi dan bahasa persatuan negara Indonesia tertuang di dalam UndangUndang Dasar 1945 Pasal 36 Bahasa Negara ialah Bahasa Indonesia. Hal ini dengan jelas telah menerangkan posisi yang dimiliki oleh bahasa Indonesia yang telah diatur dalam hukum dan tidak bisa diganggu gugat. Adapun fungsi bahasa Indonesia adalah sebagai bahasa resmi kenegaraan, pengantar pendidikan, komunikasi tingkat nasional, transaksi niaga, dokumentasi, sarana pengembangan pembinaan, perlindungan, pemanfaatan 
ilmu pengetahuan, teknologi, seni, dan medua massa. Di era globalisasi ini, maraknya penyalahgunaan bahasa yang serampangan dengan cara mencampurcampur bahasa Indonesia dengan bahasa asing ataupun bahasa gaul membuat kita resah terhadap nasib perkembangan dan keeksistensian bahasa Indonesia. Generasi muda lebih cenderung sering menggunakan gaul daripada menggunakan bahasa Indonesia yang baik dan benar.

Generasi muda zaman sekarang juga cenderung lebih cuek dengan hal-hal tentang negaranya. Di Indonesia sendiri dari jumlah 255 juta penduduk yang telah tercatat, terdapat 81 juta merupakan generasi milenial atau berusia 17-37 tahun. Hal ini berarti Indonesia memiliki banyak kesempatan untuk membangun eksistensi bahasa Indonesia dalam dunia Internasional. Dengan banyaknya jumlah generasi milenial di Indonesia, maka ini menjadi peluang yang bagus untuk melebarkan sayap eksistensi bahasa Indonesia menjadi bahasa Internasional. Karakter generasi milenial yang dikenal visioner dan menguasai teknologi dapat menjadi basis untuk mengenalkan bahasa Indonesia di dunia Internasional. Apalagi dengan zaman sekarang bahasa Indonesia sudah banyak digunakan oleh negaranegara lain. Oleh karena itu, kita sebagai generasi milenial yang mahir dalam teknologi sudah sepatutnya bangga dengan itu bisa berupa menggunakan bahasa Indonesia dalam kehidupan sehari-hari.

\section{Pengaruh Bahasa Gaul terhadap Perkembangan Bahasa Indonesia}

Berbahasa sangat erat kaitannya dengan budaya sebuah generasi. Kalau generasi negeri ini kian tenggelam dengan pengkhususan bahasa Indonesia yang lebih dalam, mungkin bahasa Indonesia akan semakin sempoyongan dalam memanggul bebannya sebagai bahasa Nasional dan identitas bangsa. Dalam kondisi demikian, diperlukan pembinaan dan pemupukan sejak dini kepada muda agar mereka tidak mengikuti pembusukan itu. Pengruh arus globalisasi dalam identitas bangsa tercermin pada perilaku masyarakat yang mulai meninggalkan bahasa Indonesia dan terbiasa menggunakan bahasa gaul. Saat ini jelas di masyarakat sudah banyak adanya penggunaan bahasa gaul dan hal ini diperparah lagi dengan generasi muda Indonesia juga tidak terlepas dari pemakaian bahasa gaul. Bahkan, generasi muda inilah yang paling banyak menggunakan dan menciptakan bahasa gaul di masyarakat.

\section{Menurunnya Derajat Bahasa Indonesia}

Bahasa Indonesia masih sangat muda usianya dibandingkan dengan bahasa lainnya, tidak mengherankan apabila dalam sejarah pertumbuhannya, perkembangan bahasa yang lebih maju. Seperti kita ketahui bahwa perkembangan ilmu pengetahuan dewasa ini dikuasai oleh bangsa-bangsa barat. Merupakan hal yang wajar apabila bahasa mereka pula menyertai penyebaran ilmu pengetahuan tersebut ke seluruh dunia. Indonesia sebagai negara yang baru berkembang tidak mustahil menerima pengaruh dari negara asing.

Kemudian masuklah ke dalam bahasa Indonesia istilah-istilah kata asing karena memang makna yang dimaksud oleh kata-kata asing tersebut belum ada dalam bahasa Indonesia. Sesuai sifatnya sebagai bahasa represif, sangat membuka kesempatan untuk itu. Melihat kondisi 
seperti ini, timbullah beberapa anggapan yang tidak baik. Bahasa Indonesia dianggap sebagai bahasa yang miskin, tidak mampu mendukung ilmu pengetahuan yang modern. Pada pihak lain muncul sikap mengagung-agungkan bahasa Inggris dan bahasa asing lainnya. Dengan demikian timbul anggapan mampu berbahasa Inggris atau bahasa asing merupakan ukuran derajat seseorang. Akhirnya motivasi untuk belajar menguasai bahasa asing lebih tinggi daripada belajar dan menguasai bahasa sendiri. Kenyataan adanya efek sosial yang lebih baik bagi orang yang mampu berbahasa asing daripada bahasa Indonesia, hal ini lebih menurunkan lagi derajat bahasa Indonesia di mata orang awam.

\section{PENUTUP}

Penggunaan bahasa Indonesia di kalangan remaja saat ini hampir sudah tidak ada yang menggunakannya dengan benar, sedikit sekali remaja yang menggunakan bahasa Indonesia dengan benar. Selang waktu yang berjalan, pengguna bahasa Indonesia dengan benar telah di geser dengan bahasa-bahasa yang tidak di kenal. Dikarenakan datangnya penduduk luar negeri ke dalam negeri, yang membaur bahasa Indonesia dengan bahasa asing.

Bahasa yang digunakan remaja pada saat ini diantaranya adalah bahasa prokem atau bahasa gaul, bahasa asing dan bahasa daerah. Bahasa Indonesia tidak digunakan sebagaimana mestinya dikarenakan beberapa faktor antara lain faktor dari luar dan faktor dari dalam. Beberapa cara yang dapat dilakukan untuk meningkatkan minat para remaja kita agar menggunakan bahasa Indonesia yang baik dan benar adalah dengan tindakan yang nyata dari diri sendiri, masyarakat dan pemerintah. Karena itu merupakan elemen penting untuk perubahan agar remaja, nasyarakat dan pemerintah Indonesia memiliki rasa bangga akan bahasanya sendiri. Bahasa Indonesia merupakan alat pemersatu bangsa, sebagai identitas Bangsa Indonesia dan sebagai lambang kebanggan nasional.

\section{DAFTAR PUSTAKA}

Chaer, Abdul. 2014. Lingusitik Umum. Jakarta: Rineka Cipta.

Danuarta, Johan. 2016. Penggunaan Bahasa Indonesia di Kalangan Remaja. (Online, http://johandanuartanainggolan.blogspot.com/2016/06/penggunaan-bahasa-indonesiadi-kalangan.html, Diakses 24 Desember 2018).

Mansyur, Umar. 2016. Bahasa Indonesia dalam Belitan Media Sosial: Dari Cabe-Cabean Hingga Tafsir Al-Maidah 51. In Prosiding Seminar Nasional \& Dialog Kebangsaan dalam Rangka Bulan Bahasa 2016 (pp. 145-155). Fakultas Ilmu Budaya, Unhas. https://doi.org/10.31227/osf.io/7vpjh

Mansyur, Umar. 2018. Belajar Memahami Bahasa Generasi Milenial. https://doi.org.10.31227/osf.io/sxhp8.

Mansyur, Umar. 2018. Sikap Bahasa dan Pembelajaran Bahasa Indonesia di Perguruan Tinggi. In 1st International Conference of Asosiasi Linguistik Terapan Indonesia UMI 2018. https://doi.org/10.31227/osf.io/te3df

Purwito. 2012. Perkembangan Indonesia. (Online, http://coffelatte2.blogspot.com/2012/09/ perkembangan-indonesia-di.html, Diakses 2 Januari 2018). 
Putri, Nimas Permata. 2017. Eksistensi Bahasa Indonesia pada Generasi Milennial. Jurnal Widyabastra, 5(1), 45-47.

Rahayu, Arum Putri. 2015. Menumbuhkan Bahasa Indonesia Yang Baik dan Benar dalam Pendidikan dan Pengajaran. Jurnal Paradigma, 2(1), 15-20.

Suprihatien. 2016. Fenomena Penggunaan Bahasa Kekinian di Kalangan Mahasiswa. Jurnal Inovasi, 18(2), 77-79.

Vener, Francisca Chlaudia. 2016. Penggunaan Bahasa Indonesia di Kalangan Remaja. (Online, https://www.pontianakpost.co.id/penggunaan-bahasa-indonesia-di-kalanganremaja, Diakses 24 Desember 2018). 